\title{
Ecological investigation of Urpad beel: A major wetland of Goalpara district of Assam, India.
}

Upen Deka* and Tapan Dutta

Department of Botany, Jawaharlal Nehru College, Boko, Kamrup, Assam, India.

Received: 3/4/2018; Revised: 3/12/2018; Accepted: 3/20/2018

\begin{abstract}
The present investigation deals with the ecological study of Urbad beel of Goalpara district of Assam with reference to aquatic plant community. The study was carried out during the year 2016 to 2017. Diversity indices viz. Shannon-Weiner diversity index, Simpson diversity index, Menhinick diversity index and Concentration of dominance were calculated to show the plant community structure of the wetland. A total of 93 aquatic macrophytic plant species belonging to 74 genera and 45 families have been reported from the wetland. Based on IVI value, Eichbornia crassipes was the most dominant species (IVI= 22.54) followed by Hygroryza aristata (IVI= 19.96), Arundo donax $(I V I=8.21)$ respectively whereas Cyperus brevifolius (IVI= 0.768) showed the lowest IVI value among all the life forms of the aquatic macrophytes of the wetland. Results showed that anthropogenic disturbances inside the wetland areas are the prime factor for losing aquatic plant community of the wetland. The obtained Shannon -diversity index values (3.06 and 2.18) both in summer and winter seasons indicate the further degradation of the wetland. Therefore, anthropogenic activities inside the wetland areas should be prevented for the sustainable existence of the wetland as well as the livelihood of the fringe villagers.
\end{abstract}

Key words: Anthropogenic disturbances, diversity index, IVI, plant community, sustainable existence, livelihood.

\section{Introduction}

Aquatic and wetland plants are mostly confined to the marshes and wetland habitats. These waterlogged or wet soils form the diverse habitats for specific aquatic plant communities, which in a broader sense are known as wetland. They are ecologically characterized by the presence of water i.e. fresh, brakish, saline or euthropic; hydric soil; at least a few hydrophytic vegetation and also by the absence of flood intolerant vegetation.

Plant sociology or phytosociology is defined as the discipline which concerns itself with the study of vegetation as such, with its floristic composition, structure, development and distribution, whereas the term ecology is restricted to the study of the habitat (cf. Tansley, 1920). The phytosociological characters such as frequency, density and abundance are exclusively influenced not only by natural but also anthropogenic activities as well. The natural disturbances in the form of flood in nearby the wetland areas seriously affect the plant composition structure. Sometimes, heavy siltation as a result of flood in the wetlands areas submerges the macrophytic species composition resulting into the change of physicochemical properties of soil as well as water of the wetland ecosystem and finally establishment of some alluvial grassland (Deka and Sarma, 2014). This changed of physicochemical characteristics of soil and water of the wetlands also alter the aquatic plant communities. Besides, heavy grazing by domestic buffaloes inside the wetland

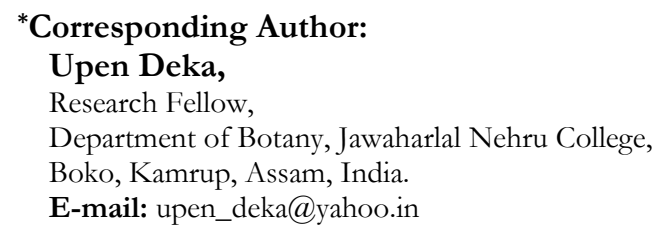

areas also affects the aquatic plant community structure of the wetlands. The dynamics of aquatic vegetation is determined by array of factors which include excessive collection of plant resources, grazing regime, climatic fluctuation and to some extent the soil characteristics.

Two factors, number of species and importance values (number, biomass, productivity) of individuals, determine the species diversity of a community (Odum, 1996). Importance Value Index (IVI), a quantative parameter, is useful, as it provides an overall picture of the density, frequency and cover of a species in relation to community (Curtis and McIntosh, 1951). Aquatic communities reflect anthropogenic influence and are very useful to detect and assess human impacts (Salak et al., 2012). Wetlands in India are facing tremendous anthropogenic pressures such as rapidly expanding human population, large scale changes in land use and cover and improper use of watersheds, which in turn greatly influence the aquatic ecosystem (Prasad et al., 2002; Singh et al., 2006; Kumar and Gupta, 2009; Ramachandra, 2010; Anand, et al. 2010; John and Francis, 2010).

Aquatic macrophytic diversity and its role in understanding the wetland ecosystem dynamics have tremendous significance. Several workers have done significant works on the phytosociology of different macrophytes in different freshwater bodies of India (Billore and Vyas, 1981; Biswas and Calder, 
1936; Cottam and Curtis, 1956; Crowder, 1977; Dey and Kar, 1989; Kar and Barbhuiya, 2000; Misra, 1979). Limited studies of wetlands of Assam have been carried out by different workers (Borah and Sarma, 2012; Nath, 2012; Baruah, et al, 2011; Dutta, et al, 2010; Dutta, et al. 2011; Sarma and Saikia, 2011). Basic and preliminary informations related to the present investigations have been collected from the wetland of the study sites which influence the socioeconomic condition of people and also affecting the overall environment of the study site.

Though many workers have been carried out on the ecological studies of different wetlands of India and rest of the countries, no detail studies about the ecology of Urpad beel of Goalpara district of Assam, India have been carried out yet. However, this wetland is very significant one of the district as it contains high biological diversity which support livelihood of the people living around its vicinities. Unfortunately, such an important wetland of the district is now facing serious threats of degrading due to several natural as well as man- made activities. Therefore, the present study aims to investigate the ecology of Urpad beel in contest to anthropogenic disturbances in the wetland.

\section{Study area}

Urpad beel is the largest beel of Goalpara district situated between latitude $26^{\circ} 05^{\prime} 05^{/ /} \mathrm{N}$ to $26^{\circ} 06^{\prime}$ $45 / / \mathrm{N}$ and longitude $90^{\circ} 34 / 08^{/ /} \mathrm{E}$ to $90^{\circ} 37 / 45^{/ /}$ $\mathrm{E}$ on the southern part of the river Brahmaputra. It is about $12 \mathrm{~km}$ from Goalpara town, the district headquarters and is approximately $150 \mathrm{~km}$ from the state capital i.e. Guwahati. It comprises of a waterspread of 700 ha. It is also connected with two more water bodies viz., Patakata and Matia beels to the east, which makes the total area of the wetland more than 1,000 ha. The river Jinari originates from the Garo Hills of Meghalaya in the southern side of the beel, passes by the side of the beel to the north and north-east directions before meeting the river Brahmaputra.

\section{Materials and Methods}

The quadrat method of vegetation sampling technique was used for density, frequency dominance and IVI (Misra, 1969). Species were collected according to the traditional herbarium technique (Jain and Rao, 1976). Collected plant species were identified with the help of herbarium, Department of Botany, Gauhati University, Guwahati.

The diversity indices of aquatic macrophytes were calculated by using the following formulas:

a) The Shannon and Weiner diversity index $(\bar{H})$ is calculated by using the formula given by Shannon and Weaver (1963)

$$
\overline{\mathbf{H}}=-\Sigma \text { pi ln pi }
$$

Where, $\mathrm{pi}=$ the proportion of importance value of the ith species $(\mathrm{pi}=\mathrm{ni} / \mathrm{N}$, ni is the importance value of ith species and $\mathrm{N}$ is the importance value of all the species).

b) Simpson's index of Dominance (D) is calculated by using the formula given by Simpson (1949)

$$
\mathrm{D}=\Sigma(\mathbf{P i})^{2}
$$

Where, $\mathrm{pi}=$ the proportion of important value of the ith species ( $\mathrm{pi}=\mathrm{ni} / \mathrm{N}$, ni is the importance value of ith species and $\mathrm{N}$ is the importance value of all the species.

c) Species richness (d) is calculated by using the formula given by Menhinick (1964)

$$
\mathbf{d}=\mathbf{S} / \sqrt{ } \mathbf{N}
$$

where, $\mathrm{S}=$ Total number of species, and $\mathrm{N}=$ Total number of individuals of all the species.

d) The concentration of dominance $(C d)$ is calculated by using the formula given by Simpson (1949).

$$
C d=(\mathrm{Ni} / \mathrm{N})^{2}
$$

where, $\mathrm{Ni}=$ Proportion of individuals belonging to the ith species, $\mathrm{N}=$ Total number of individuals.

\section{Data Source \& Methodology for Land Cover} Change Analysis:

This study was conducted by examining the patterns of land use changes by using Remote Sensing (coupled with ground survey) and GIS to distinguish different land use classes as described by several workers (Anderson, 1971, Jakubauskas et al. 1998; Lucas et al. 1993; Jensen et al. 1995) and also to identify the factors, affecting the land cover changes in and around the wetland of the study sites.

\section{Data Source:}

To analyze the land use change dynamics of the wetlands of the study sites multi dated, multi seasons satellite imageries were used. Besides this, the Survey of India topographical sheet at 1:50,000 scales were used for delineation the wetland boundary and to generate baseline information for the study area. The details of the datasets used in this study are shown in Table-1.

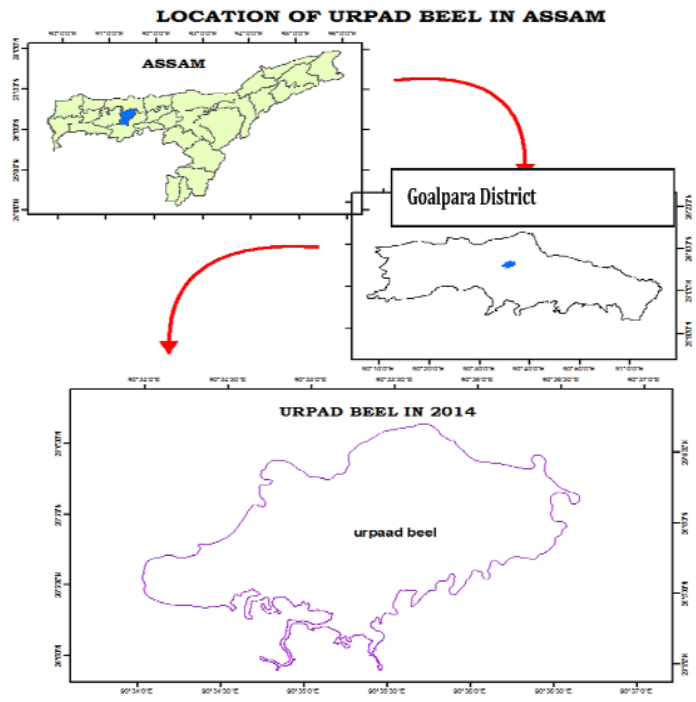

Figure 1. Location map of the study area 


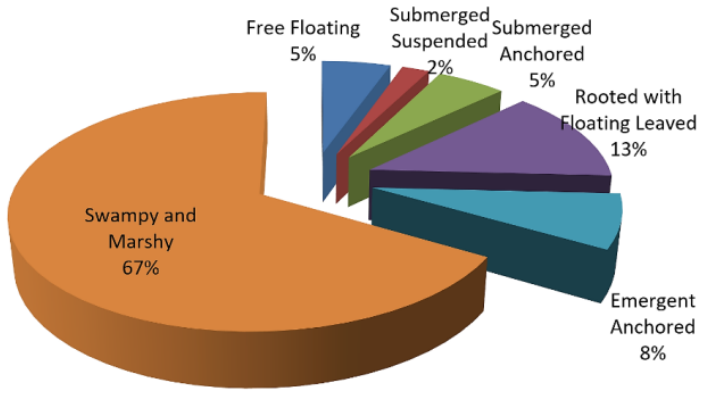

Figure 2. Types of aquatic macrophytes of Urpad beel

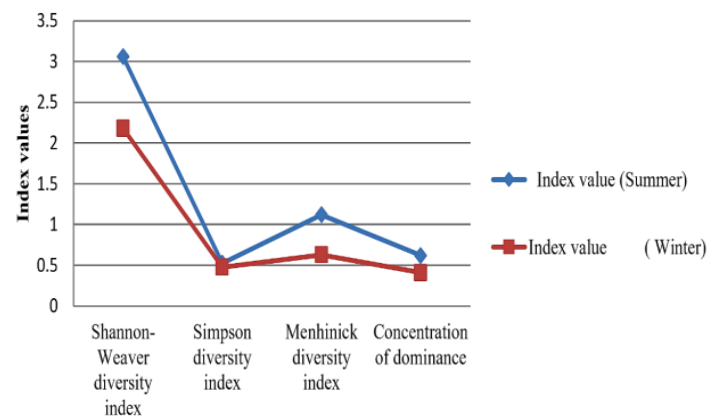

Figure 3: Diversity indices of aquatic macrophytes of Urpad beel

Table 1. Datasets used for monitoring the LU/LC change:

\begin{tabular}{cccc}
\hline \multirow{2}{*}{ Data Type } & Path/ Row & \multicolumn{2}{c}{ Date of acquisition } \\
\cline { 3 - 4 } & & Pre-Monsoon & Post-Monsoon \\
\hline Landsat TM & $136 / 42,135 / 42$ & 1987 (February \& March) & 1987 (September \& October) \\
Landsat TM & $136 / 42,135 / 42$ & 1999 (February \& March) & 1999 (September \& October) \\
IRS LISS III & $109 / 52,111 / 52$ & 2013 (February \& March) & 2013 (September \& October) \\
\hline
\end{tabular}

Source: Satellite imagery of Landsat TM of 1987 and IIRS P6 III of 1999 and 2013, NASA's Global Land Cover Facilittator \&National Remote Sensing Centre, Hyderabad.

Table 2. Types of aquatic macrophytes of the wetland of the study site:

\begin{tabular}{ccc}
\hline S1. No. & Types & Number of species \\
\hline 1 & Free Floating & 05 \\
2 & Submerged Suspended & 02 \\
3 & Submerged Anchored & 05 \\
4 & Rooted with Floating Leaved & 12 \\
5 & Emergent Anchored & 07 \\
6 & Swampy and Marshy & 62 \\
\hline
\end{tabular}

Table 3. Phytosociological characterisctics of aquatic plant species of Urpad beel

\begin{tabular}{|c|c|c|c|c|c|}
\hline Name of the plant species & RD & RF & RA & IVI & Life span \\
\hline \multicolumn{6}{|l|}{ Free Floating (FF) } \\
\hline Eichbornia crassipes (Mart) Solms. & 11.7 & 2.704 & 8.14 & 22.54 & $\mathrm{P}$ \\
\hline Lemna perpusilla Torr. & 0.11 & 0.568 & 0.5 & 1.16 & A \\
\hline Pistia stratiotes $\mathrm{L}$. & 0.954 & 0.798 & 1.34 & 3.09 & A \\
\hline Salvinia molesta & 0.26 & 0.793 & 0.734 & 1.78 & A \\
\hline Spirodela polyrbiza (L.) Schleid & 0.086 & 0.798 & 0.244 & 1.12 & $\mathrm{P}$ \\
\hline Total (FF) & & & & 29.69 & \\
\hline \multicolumn{6}{|l|}{ Submerged Suspended (SS) } \\
\hline Ceratophyllum demersum L. & 0.14 & 0.568 & 0.66 & 1.37 & $\mathrm{P}$ \\
\hline Utricularia aurea Lour. & 0.77 & 1.83 & 0.61 & 3.2 & A \\
\hline Total (SS) & & & & 4.57 & \\
\hline \multicolumn{6}{|l|}{ Submerged Anchored (SA) } \\
\hline Hydrilla verticillata (L. f) Royle & 0.11 & 0.568 & 0.5 & 1.16 & A \\
\hline Ottelia alismoides (L.) Pers. & 0.14 & 0.568 & 0.66 & 1.37 & A \\
\hline Potamogeton crispus $\mathrm{L}$. & 0.433 & 1.58 & 0.611 & 2.62 & A \\
\hline Vallisneria natans (Lour.) Hara & 0.48 & 0.943 & 0.15 & 1.57 & A \\
\hline Myriophyllum tuberculatum Roxb. & 0.32 & 0.568 & 1.49 & 2.37 & $\mathrm{P}$ \\
\hline Total (SA) & & & & 9.09 & \\
\hline \multicolumn{6}{|l|}{ Rooted with Floating Leaved (RFL) } \\
\hline Aponogeton natans (L.) Engl. \& Krause. & 1.27 & 1.704 & 1.99 & 4.95 & $\mathrm{P}$ \\
\hline Euryale ferox Salisb. & 0.11 & 0.568 & 0.5 & 1.16 & A \\
\hline Hygroryza aristata & 10.8 & 6.545 & 2.61 & 19.96 & $\mathrm{P}$ \\
\hline Ipomoea aquatica Forsk. & 0.42 & 1.704 & 0.66 & 2.78 & A \\
\hline Nelumbo nucifera Gaertn. & 0.32 & 1.704 & 0.5 & 2.51 & $\mathrm{P}$ \\
\hline Nymphea pubescens Willd. & 0.6 & 0.568 & 2.81 & 3.98 & $\mathrm{P}$ \\
\hline Limnophila antipoda & 0.14 & 1.704 & 0.5 & 2.34 & $\mathrm{P}$ \\
\hline L. heterophylla & 0.35 & 1.136 & 0.83 & 2.31 & $\mathrm{P}$ \\
\hline L. perennis L. & 0.24 & 1.136 & 0.52 & 1.89 & $\mathrm{P}$ \\
\hline Marsilea quadrifolia $\mathrm{L}$. & 0.49 & 1.704 & 0.77 & 2.96 & A \\
\hline Trapa natans L. var bispinosa (Roxb) Makino & 1.26 & 0.793 & 0.734 & 1.78 & $\mathrm{P}$ \\
\hline T. natans L. var quadrispinosa Roxb. & 1.44 & 0.83 & 0.15 & 2.42 & $\mathrm{P}$ \\
\hline Total (RFL) & & & & 49.04 & \\
\hline \multicolumn{6}{|l|}{ Emergent Anchored Hydrophytes (EA) } \\
\hline Hymenachne acutigluma & 1.2 & 0.568 & 5.63 & 7.39 & $\mathrm{P}$ \\
\hline H. assamica & 2.23 & 2.84 & 2.18 & 7.34 & $\mathrm{P}$ \\
\hline
\end{tabular}




\begin{tabular}{|c|c|c|c|c|c|}
\hline Kyllingia brevifolia Stokes. & 5.13 & 1.17 & 0.83 & 7.12 & $\mathrm{P}$ \\
\hline Leersia hexandra SW. & 0.21 & 0.568 & 0.99 & 1.77 & $\mathrm{P}$ \\
\hline Monochoria bastata (L.) Solms & 1.16 & 1.704 & 1.82 & 4.68 & $\mathrm{P}$ \\
\hline M. vaginalis (Burm f.) Presl. & 0.46 & 1.36 & 1.08 & 2.89 & $\mathrm{P}$ \\
\hline Sagittaria sagitifolia $\mathrm{L}$. & 0.346 & 1.58 & 0.002 & 1.92 & $\mathrm{P}$ \\
\hline $\begin{array}{l}\text { Total (EA) } \\
\text { Swampy and Marshy Hydrophytes } \\
\text { (SMH) }\end{array}$ & & & & 33.11 & \\
\hline Achyranthes aspera $\mathrm{L}$. & 0.23 & 1.136 & 0.37 & 1.73 & $\mathrm{P}$ \\
\hline Adonostoma levinae & 1.25 & 1.36 & 0.58 & 3.19 & $\mathrm{P}$ \\
\hline Alternthera paronychioides St. Hill. & 0.32 & 1.7 & 0.5 & 2.51 & $\mathrm{P}$ \\
\hline A. philoxeroides (Mart) Griseb. & 0.07 & 0.568 & 0.33 & 0.969 & $\mathrm{P}$ \\
\hline Alpinia allughas & 0.81 & 2.272 & 0.95 & 4.03 & $\mathrm{P}$ \\
\hline Amaranthus viridis $\mathrm{L}$. & 0.25 & 1.704 & 0.39 & 2.33 & $\mathrm{P}$ \\
\hline Andrographis paniculata Nees. & 0.46 & 1.704 & 0.72 & 2.87 & $\mathrm{P}$ \\
\hline Arundo donax L. & 2.54 & 1.704 & 3.97 & 8.21 & $\mathrm{P}$ \\
\hline Centella asiatica (L.) Urban & 0.11 & 0.568 & 0.5 & 1.16 & $\mathrm{P}$ \\
\hline Chrysopogon aciculatus Trin. & 0.14 & 1.136 & 0.75 & 2.02 & $\mathrm{P}$ \\
\hline Cardiospermum halicacabum L. & 0.693 & 1.58 & 0.978 & 3.25 & $\mathrm{P}$ \\
\hline Cassia alata $\mathrm{L}$. & 1.38 & 1.943 & 0.92 & 4.24 & $\mathrm{P}$ \\
\hline C. tora $\mathrm{L}$. & 1.37 & 1.704 & 2.15 & 5.22 & $\mathrm{P}$ \\
\hline Costus speciosus (Koen. ex Retz.) J. E. Smith & 0.693 & 1.58 & 0.978 & 3.25 & $\mathrm{P}$ \\
\hline Cleome gynandra $\mathrm{L}$. & 0.32 & 2.272 & 0.84 & 3.42 & $\mathrm{P}$ \\
\hline C. viscosa L. DC. & 0.21 & 1.136 & 0.5 & 1.84 & $\mathrm{P}$ \\
\hline Carex baccans L. & 0.57 & 0.88 & 0.69 & 2.14 & A \\
\hline Cynondon dactylon (L.) Pers & 2.15 & 1.704 & 3.37 & 7.21 & $\mathrm{P}$ \\
\hline Cyperus brevifolius (Rottb) Endl. Ex. Hassk & 0.04 & 0.568 & 0.17 & 0.768 & A \\
\hline C. compressus $\mathrm{L}$. & 0.46 & 1.36 & 1.08 & 2.89 & A \\
\hline C. difformis $\mathrm{L}$. & 0.85 & 1.704 & 1.32 & 3.87 & A \\
\hline C. digitatus Roxb. Var. bountii. & 0.11 & 0.568 & 0.5 & 1.16 & A \\
\hline C. iria $\mathrm{L}$. & 0.57 & 0.88 & 0.69 & 2.14 & A \\
\hline C. rotundus $\mathrm{L}$. & 1.29 & 0.943 & 0.69 & 2.91 & A \\
\hline Digitaria longiflora (Retz.) Pers. & 1.29 & 0.943 & 0.69 & 2.91 & A \\
\hline Diplazium esculentum (Retz) Sw. & 0.38 & 0.943 & 0.92 & 2.24 & $\mathrm{P}$ \\
\hline Eclipta prostrata L. & 1.16 & 2.272 & 1.37 & 4.79 & A \\
\hline Elephentopus scaber L. & 0.38 & 0.943 & 0.92 & 2.24 & A \\
\hline Enbydra fluctuans Lour. & 0.21 & 1.136 & 0.5 & 1.84 & A \\
\hline Evolvulus numularis (L.) L & 0.18 & 0.568 & 0.83 & 1.57 & A \\
\hline Euphorbia birta L. & 0.14 & 0.568 & 0.66 & 1.37 & $\mathrm{P}$ \\
\hline Fimbristylis bisumbellata (Forssk.) Bubani & 0.35 & 1.136 & 0.83 & 2.31 & A \\
\hline Garngea maderspatana & 0.07 & 0.568 & 0.33 & 0.969 & $\mathrm{P}$ \\
\hline Gnaphallum indicum Linn. & 0.86 & 0.79 & 0.61 & 2.26 & $\mathrm{P}$ \\
\hline Heliotropium indicum L. & 0.67 & 2.272 & 0.79 & 3.72 & $\mathrm{P}$ \\
\hline Hedyotis corymbosa (L) Lamk. & 0.81 & 1.704 & 1.27 & 3.78 & $\mathrm{P}$ \\
\hline I. carnea Jace. & 0.18 & 1.136 & 0.41 & 1.72 & A \\
\hline Jussiena repens $\mathrm{L}$. & 0.88 & 2.272 & 1.03 & 4.18 & $\mathrm{P}$ \\
\hline Lippia javanica (Burm.f.) Spreng & 0.18 & 0.568 & 0.83 & 1.57 & $\mathrm{P}$ \\
\hline Mezus regosa Lour & 0.07 & 0.568 & 0.33 & 0.969 & $\mathrm{P}$ \\
\hline Mikania micrantha Kunth. Ex. H.B.K. & 0.95 & 1.704 & 1.49 & 4.14 & A \\
\hline Mimosa pudica L. & 0.35 & 0.568 & 1.66 & 2.57 & A \\
\hline Oxalis corniculata $\mathrm{L}$. & 0.39 & 1.136 & 0.91 & 2.43 & A \\
\hline Panicum repens $\mathrm{L}$. & 0.81 & 1.704 & 1.27 & 3.78 & A \\
\hline Phyllanthus niruri & 0.433 & 2.38 & 0.406 & 3.21 & A \\
\hline Poa aпnиа $\mathrm{L}$. & 0.607 & 0.793 & 1.713 & 3.11 & A \\
\hline Polygonum barbatum $\mathrm{L}$. & 0.607 & 1.587 & 0.856 & 3.05 & A \\
\hline P. glabrum Willd. & 0.607 & 1.58 & 0.856 & 3.04 & A \\
\hline P. orientale $\mathrm{L}$. & 0.433 & 1.58 & 0.611 & 2.62 & A \\
\hline Ranunculus aquatalis L.var.tricophylls & 0.433 & 0.793 & 1.223 & 2.44 & $\mathrm{P}$ \\
\hline Ranunculas sclertus L. & 0.433 & 0.793 & 1.223 & 2.44 & $\mathrm{P}$ \\
\hline Rungia parviflora (L.) Nees. & 0.346 & 1.587 & 0.489 & 2.42 & A \\
\hline Rotala densiflora (Roth) Koehne & 0.346 & 1.58 & 0.489 & 2.41 & A \\
\hline $\begin{array}{l}\text { R. rotundifolia (Buch.-Ham. ex Roxb.) } \\
\text { Koehne }\end{array}$ & 0.346 & 1.58 & 0.489 & 2.41 & A \\
\hline Rumex maritimus $\mathrm{L}$. & 0.346 & 0.798 & 0.978 & 2.12 & A \\
\hline Schoenoplectus articulatus L. & 0.48 & 0.943 & 1.15 & 2.57 & A \\
\hline S. grossus (L. f.) Palla & 0.173 & 0.793 & 0.489 & 1.45 & A \\
\hline Stellaria media (L.) Vill. & 0.53 & 1.72 & 0.76 & 3.01 & A \\
\hline Solanum nigrum L. & 0.26 & 0.793 & 0.734 & 1.78 & $\mathrm{P}$ \\
\hline Vicia alba (Tourn.) L. & 1.63 & 1.886 & 0.95 & 4.47 & A \\
\hline Vetiveria zizanioides (L.) Nash & 2.05 & 1.36 & 2.15 & 5.56 & A \\
\hline Xanthium strumarium L. & 0.21 & 0.886 & 0.64 & 1.73 & A \\
\hline Total (SMH) & & & & 174.51 & \\
\hline $\begin{array}{l}\text { Grand } \\
(\mathrm{SS})+(\mathrm{SA})+(\mathrm{RFL})+(\mathrm{EA})+(\mathrm{SMH})\end{array}$ & & & & 300.01 & \\
\hline
\end{tabular}

$\mathrm{RD}=$ Relative Density, RF= Relative Frequency, RA=Relative Abundance, IVI=Importance Value Index, $\mathrm{A}=$ Annual, $\mathrm{P}=$ Perennial 
Table 4. Seasonal variation in diversity indices of plant community of Urpad beel

\begin{tabular}{lcc}
\hline \multicolumn{1}{c}{ Diversity indices } & Index value (Summer) & Index value (Winter) \\
\hline Shannon- Weaver diversity index & 3.06 & 2.18 \\
Simpson diversity index & 0.527 & 0.478 \\
Menhinick diversity index & 1.12 & 0.63 \\
Concentration of dominance & 0.62 & 0.41 \\
\hline
\end{tabular}

Table 5. LU/LC Changes of the wetland during 1987 to 2013 (Areas in hectares)

\begin{tabular}{lllllll}
\hline & \multicolumn{2}{c}{ 1987 } & \multicolumn{2}{c}{ 1999 } & \multicolumn{2}{c}{ 2013 } \\
Land use classes & Pre Monsoon & Post Monsoon & Pre Monsoon & Post Monsoon & Pre Monsoon & Post Monsoon \\
\hline Cropland (Rabi) & 956.54 & 775.43 & 932.88 & 612.01 & 874.29 & 574.78 \\
Cropland (Kharif) & 1511.02 & 1608.17 & 1569.88 & 1697.05 & 1569.88 & 1697.05 \\
Agriplantation & 845.39 & 847.39 & 934.1 & 934.2 & 1134.43 & 1138.23 \\
Water Body & 589.14 & 645.22 & 583.87 & 698.45 & 583.87 & 698.45 \\
\hline
\end{tabular}

Source: Source: Satellite imagery of Landsat TM of 1987 and IIRS P6 III of 1999 and 2013, NASA's Global Land Cover Facilittator \& National Remote Sensing Centre, Hyderabad

\section{Results and Discussion}

During the study period 93 macrophyic species belonging to 74 genus and 45 families have been reported from Urpad beel. Most dominant families were Cyperaceae representing 12 species followed by Poaceae (11 species) and Asteraceae (8 species).

Aquatic macrophytic species were categorized into six types such as Free Floating (FF), Submerged Suspended (SS), Submerged Anchored (SA), Rooted with Floating Leaved (RFL), Emergent Anchored (EA), Swampy and Marshy (SM) by following the system of Weaver and Clement (1929) and Daubenmire (1947). In terms of number of plant species, swampy and marshy species showed the largest number (62 species) followed by Rooted with floating leaved (12 species), Emergent Anchored (07), submerged anchored and free floating with 5 species each and submerged suspended ( 2 species) representing 67\%,13\%, 8\%, $5 \%, 5 \%$ and $2 \%$ respectively (Table 2 ).

It has been observed that Free floating hydrophytes i.e. Eichbornia crassipes was the most dominant species $(\mathrm{IVI}=22.54)$ whereas Swampy and Marshy hydrophytes i.e. Cyperus brevifolius (IVI= 0.768) showed the lowest IVI value among all the life forms of aquatic macrophytes of the wetland (Table 3).

Among the free floating hydrophytes, Eichhornia crassipes was found to be most dominant species in Urpad beel. Highest IVI value of this species was found to be 22.54. This is followed by followed by Pistia stratiotes (IVI= 3.09).

Among submerged hydrophytes, Utricularia aures was most dominant species (IVI=3.2) whereas Ceratophyllum demersum was the least dominant species $(\mathrm{IVI}=1.37)$ in Urpad beel during the study period. Potamogeton crispus showed highest IVI value (IVI $=2.62)$ and Hydrilla verticillata showed lowest $(\mathrm{IVI}=1.16)$ among submerged anchored hydrophytes. Similarly, Hygroryza aristata showed the highest IVI values (19.96) and Euryale ferox showed the lowest IVI value (1.16) during the study period.
Highest IVI value among Emergent Anchored hydrophytes was represented by Hymenachne acutigluma and Leersia hexandra showed the lowest IVI values $(\mathrm{IVI}=1.77)$.

Among Swampy and Marshy hydrophytes, Arundo donax showed highest IVI value (IVI= 8.21). This is because the devastating flood caused by the overflowing of the river Jinari during 2013 has caused heavy siltation inside the wetland areas resulting into devepolpment of some alluvial grassland patches such as Arundo donax, Vetiveria zizanioides inside the wetland areas.

The Shannon-Weaver diversity index value was found to be 3.06 and 2.18 during the summer season and winter seasons of the study period. Maximum values of the diversity index were found during the summer season. It may due to the luxuriant growth of the macrophytes due to the availability of water along with the nutrients leached from the catchment areas of the wetland during the summer season. Simpson index value was highest (0.527) during the summer season whereas minimum value $(0.478)$ was found during the winter season. Menhinick index was found highest value (1.12) during the summer season of the study period while minimum value (0.63) was found during the winter season. The concentration of dominance was maximum (0.62) during the summer season while it was minimum (0.41) in the winter season of the study period (Table 4). Maximum concentration of dominance during the summer season reflects the dominance of few species only. During the winter season diversity of macrophytes were found to decrease due to the scarcity of water levels in the wetland as well as the removal of aquatic macrophytes by the local villagers for Boro rice cultivation inside the wetland areas. Besides aquatic plant species were also found to remove by the fishermen communities living surrounding the wetland areas for fishing purposes.

Rabi Cropland has been decreased by 82.25 hectares $(8.59 \%)$ in pre-monsoon season while during postmonsoon season its area has been decreased by 
200.65 hectares (25.87\%) from 1987 to 2013. Kharif cropland has been increased by 58.86 hectares (3.89\%) in Urpad beel from 1987 to 2013 during pre-monsoon season while during post- monsoon season 88.88 hectares areas has been increased representing $5.52 \%$. Agriplantation has been increased by 289.04 hectares and 290.84 hectares in pre-monsoon and post monsoon season representing $34.19 \%$ and $34.32 \%$ respectively (Table 5).

Significantly, the water spread area of Urpad beel has been increased by 53.23 hectares $(8.24 \%)$ during the post- monsoon season from 1987 to 2013. It is mainly due to overflowing of the river Jinari originates from the West Garo Hills of Meghalaya in the southern side of the beel which is passing by the side of the beel to the north and north-east directions before meeting the Brahmaputra. Sandy area has also been decreased by 6.42 hectares and 7.42 hectares respectively from 1987 to 2013 representing $3.53 \%$ and $5.04 \%$ respectively.

The unscientific land use practices in the adjacent Garo hill along with forest clearing in uplands exert a major pressure on the wetland leading to soil erosion. It has caused siltation leading to vertical shrinkage of the wetland areas. The increasing population of the surrounding villages of the wetland of the study sites is also another major cause of degradation of the wetland. These threats have resulted not only in shrinking of the wetland area but also deteriorated the natural environment for the survival of different flora and fauna within the wetland ecosystem as well. However, Due to the increase literacy rate among the inhabitants and also for improvement of socioeconomic condition of the fringe villages of the wetlands of the study sites, the dependency of the people on the wetlands have been found to be decreased over the last few years.

\section{Conclusion}

Satellite data from the year 1987 to 2013 shows that wetland of the present study sites is shrinking from year to year. It is mainly due to illegal land use practices by the local villagers inside the wetland areas and this kind of land use classes has negative impact not only on aquatic plant community but also the overall health of the wetland ecosystem as well. Due to continuous deforestation and mining activities going on in the surrounding hill of Urpad beel, the wetland is becoming very shallow. This widespread deforestation on the hills has been a significant factor behind accumulation of heavy deposits of silt and clay on the bed of the wetland. Therefore, concerned government authority should take responsibility to ban such kind of illegal activities occurring surrounding the wetland. At the same time initiative should also be taken to developed as fisheries and promotes for tourist attraction.

\section{Acknowledgement}

Authors are gratefully acknowledged to the University Grants Commission (UGC) Govt. of India for providing the financial assistance under Major Research Project.

\section{References}

1. Anand MO, J Krishnaswamy, A Kumar and A Bali. "Sustaining biodiversity conservation in humanmodified landscapes in the Western Ghats: Remnant forests matter", Biological Conservation 143, (10) (2010): 2363-2374.

2. Anderson JR. "Land use classification schemes used in selected recent geographic application of remote sensing", Photogrammetric Engineering and Remote Sensing 37, (4) (1971): 379-387.

3. Baruah D, S Borah, LP Hazarika, R Dutta, B Bakalial, SP Biswas and SK Sarma. "A simple diagnostic tool for measuring river health - example from a tropical snow fed river", Annal of Biological Research 2, (5) (2011):432-443.

4. Billore DK and IN Vyas. "Distribution and production of macrophytes in Pichhola Lake, Udaipur", International Journal of Ecological Science 7, (1981):45-54.

5. Biswas KP and CC Calder. "Handbook of common water and marsh plants of India and Burma", 1936, New Delhi.

6. Borah B and SK Sarma. "Phytosociological investigation visa vis human impact on two wetlands of Sonitpur district of Assam, India", Journal of Advance plant Sciences 6, (5 \& 6) 2012: 91-101.

7. Cottam G and JT Curtis. "The use of distance measures in phytosociological sampling”, Ecology 37, (1956):151-160.

8. Crowder AA, JM Bristow, MR King and KS Vander. "Distribution, seasonality and biomass of aquatic macrophytes in Lake Opinicon", Naturaliste Can. 104, (1977):441-456.

9. Curtis JT and RP McIntosh. "An upland forest continum in the prairie forest border region of Wisconsin”, Ecology 32, (1951):476-98.

10. Daubenmire RF. "Plants and Environment", 1947, Wiley, New York.

11. Dey SC and D Kar. "Aquatic macrophytes of Lake Sone in Assam”, Environmental Ecology 7, (1) (1989): 253-254.

12. Deka U and SK Sarma. "Ecological studies of macrophytes of two major wetlands of Nalbari district of Assam, India”, New york Science Journal 7. (6) (2014):1-8.

13. Dutta R, B Baruah and SK Sarma. "Influence of riparian flora on the river bank health of a Himalayan River before being regulated by a large dam in North East India", Annal of Biological Research 2, (4) (2011): 268-280. 
14. Dutta R, D Hazarika, LP Hazarika, SK Sarma and B Bakalial. "A statistical overview of certain physicochemical parameters of river Subansiri in North East India”, Ecology Environment \& Conservation 16, (2) (2010): 313-318.

15. Jain SK and RR Rao. "A Hand Book of Field and Herbarium Methods", 1976, Today and Tomorrow Printers and Publishers, New Delhi.

16. Jakubauskas M, K Kindscher and D Debinski. "Multitemporal characterization and mapping of montane sagebrush communities using Indian IRS LISS III imagery", Geocarto International 13, (1998): $65-74$.

17. Jensen JR, K Rutchey, MS Koch and S Narumalani. "Inland wetland change detection in the everglades water conservation area $2 \mathrm{~A}$ using a time series of normalized remotely sensed data", Photogrammetric Engineering do Remote Sensing 61, (2) (1995):199 - 209.

18. John J and MS Francis. "Wetland algal resources of western Ghats (Idukki district region), Kerala, India", Journal of Basic and Applied Biology 4, (3) (2010): 34-41.

19. Kar D and MH Barbhuiya. "Studies on the aquatic macrophytes of Chatla Haor floodplain wetland in Cachar district in Assam", Indian Science Congress, 2000, New Delhi.

20. Kumar P and SK Gupta. "Diversity and Abundance of Wetland Birds around Kurukshetra, India", Our Nature 7, (2009): 212-217.

21. Lucas RM, GM Honzac, PJ Foody and CC Curran. "Characterizing tropical secondary forest using multi-temporal Landsat sensing imagery", International Journal of Remote Sensing 14, (1993): 3061 3067.

22. Menhinick EP. "A Comparison of some species Individuals diversity indices applied to samples of field insects", Ecology 45, (1964): 859-881.

23. Misra KC. "Manual of Plant Ecology", 1979, Oxford and IBH Publishing, New Delhi.

24. Misra R. "Ecology Work Book", 1969, Oxford and IBH, Calcutta.
25. Nath SK. "Aquatic Macrophytes of Laokhowa Wildlife Sanctuary, Assam, India”, International Journal of Engineering Research and Applications 2, (5) (2012): 1911-1913.

26. Odum EP. "Fundamentals of ecology" (third edition), 1996, Natraj publishers, Dehradun, India.

27. Prasad SN, TV Ramachandra, N Ahalya, T Sengupta, A Kumar, AK Twiwari and VS Vijayan. "Conservation of wetlands of India- A review", Tropical Ecology 43, (1) (2002): 173-186.

28. Ramachandra TV. "Wetlands: need for appropriate strategies for conservation and sustainable management", Journal of Basic and Applied Biology 4, (3) $(2010): 1-17$

29. Salak CN, S Barinova, E Acs and H Dayioglu. "Diversity and ecology of diatom from Felent creek. (Sakarya river basin), Turkey", Turkish Journal of Botany 36, (2012): 191-203.

30. Sarma SK and M Saikia. "Utilization of wetland resources by the rural people of Nagaon district, Assam", Indian Journal of Traditional Knowledge 9, (1) (2010): 145-151.

31. Shannon CE and W Weaver. "The Mathematical Theory of Communication”, 1963, Univ. Illinois Press, Urbana, p. 125.

32. Simpson EH. "Measurement of diversity", Nature (1949): 163-188

33. Singh AK, RK Panday and S Singh. "Understanding wetlands”, 2006, Everyman's science XII, pp. 116-119.

34. Tansley AG. "The classification of vegetation and the concept of development", Journal of Ecology 8 , (1920): 114.

35. Weaver JE and FE Clements. "Plant Ecology", First Edition, 1929, Mc Graw - Hill, New York.

\section{Cite this article as:}

Upen Deka and Tapan Dutta. Ecological investigation of Urpad beel: A major wetland of Goalpara district of Assam, India. Annals of Plant Sciences 7.4 (2018) pp. 2112-2118.

http://dx.doi.org/10.21746/aps.2018.7.4.7

Source of support: University Grants Commission (UGC), Govt. of India.

Conflict of interest: $\mathrm{Nil}$ 